\title{
Expression of proliferating cell nuclear antigen in the endometrium of mares during estrus and at early diestrus
}

\author{
Expressão do antígeno núcleo celular proliferante no endométrio de éguas \\ durante o estro e início do diestro
}

\author{
Geórgia Duna MANSOUR'; Lio MOREIRA²; Ana Maria Reis FERREIRA ${ }^{3}$ \\ ${ }^{1}$ Universidade Federal Fluminense, Programa de Pós-Graduação em Patologia, Niterói - RJ, Brazil \\ ${ }^{2}$ Universidade Federal do Estado do Rio de Janeiro, Instituto de Biologia, Laboratório de Patologia Geral, Rio de Janeiro - RJ, Brazil \\ ${ }^{3}$ Universidade Federal Fluminense, Faculdade Veterinária, Departamento de Patologia e Clínica Veterinária, \\ Setor de Anatomia Patológica Veterinária, Niterói - RJ, Brazil
}

\begin{abstract}
Immunohistochemical expression of proliferating cell nuclear antigen (PCNA) was evaluated in the endometrium of mares during estrus and at early diestrus. Three samples were collected by endometrial biopsy from 10 mares, on estrus/ second day, in the ovulation day and seven days after the ovulation day. PCNA expression was high in luminal epithelium and low in endometrial glands on samples taken on estrus/second day and on the ovulation day $(\mathrm{p}<0.05)$. For samples collected on the seventh day following ovulation, the averaged PCNA immunostaining was higher in glandular epithelium $(\mathrm{p}<0.05)$. The study revealed that luminal epithelial cells exhibit higher proliferation during estrus and glandular epithelial cells exhibited higher proliferation during diestrus.
\end{abstract}

Keywords: Cell proliferation. Endometrium. Immunohistochemical. Mare. PCNA.

\section{Resumo}

A expressão do antígeno núcleo celular proliferante (ANCP) foi avaliada no endométrio de éguas durante o estro e início do diestro. Em cada uma de dez éguas foram efetuadas biópsias do endométrio em três momentos dos respectivos ciclos reprodutivos: segundo dia do estro, dia da ovulação e sete dias após a ovulação. Nas amostras colhidas no segundo dia do estro e no dia da ovulação, a expressão do ANCP foi elevada no epitélio luminal e baixa nas glândulas endometriais $(\mathrm{p}<0,05)$. Nas amostras colhidas no sétimo dia após a ovulação, a média de ANCP imunologicamente corado foi maior no epitélio glandular $(\mathrm{p}<0,05)$. O estudo revelou que as células do epitélio luminal apresentaram a maior proliferação durante o estro e que as células epiteliais glandulares apresentaram a maior proliferação durante o diestro.

Palavras-chave: Proliferação celular. Endométrio. Imuno-histoquímica. Égua. ANCP.

\section{Introduction}

Equine endometrium, particularly the luminal and glandular endometrial epithelium, consists of labile cells, which are in continuous reposition process (PRIEDKALNS, 1993; HAFEZ; JAINUDEEN; ROSNINA, 2004). This cell proliferation-anddeath process, as well as the morphological and physiological changes that occur during the estrous cycle (MANSOUR; HENRY; FERREIRA, 2003; MANSOUR et al., 2004), is controlled by the ovarian steroid hormones (BROW, 1999; GERSTENBERG; ALLEN; STEWART, 1999; HAFEZ; JAINUDEEN; ROSNINA, 2004). Mares show reduced fertility during the transition period of seasonal anoestrous, where the endometrium does not respond properly to trophic stimuli by steroid hormones, a fact that accounts for lower pregnancy rates during the seasonal transition period (KENNEY, 1978; KENNEY; DOIG 1986; EIGENHEER-MOREIRA et al., 2007).

The most common method for identifying proliferated cells in tissue sections without the use of

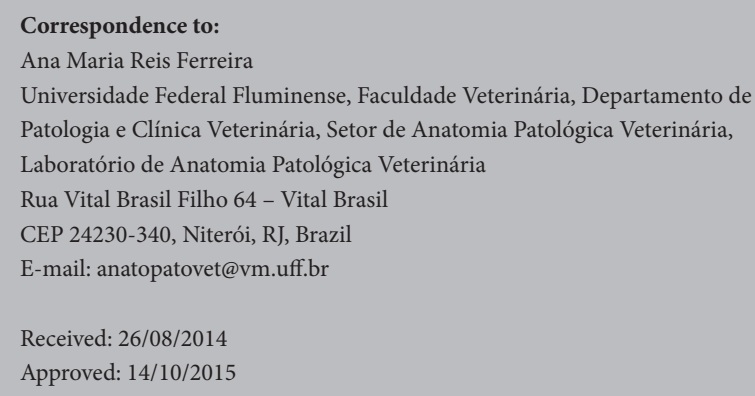


BrdU (a halogenated derivative of thymidine) has been the immunohistochemical method for proliferating cell antigens (GERSTENBERG; ALLEN; STEWART, 1999; LAI et al., 2000; MUSKHELISHVILI et al., 2003). Initially described by Miyachi, Fritzler and Tan (1978), the proliferating cell nuclear antigen (PCNA) is an auxiliary protein of DNA polymerase $\delta$ and $\varepsilon$, the enzymes that are needed for DNA synthesis (KELMAN, 1997). Expression of PCNA increases during G1 phase of cell cycle, reaches its expression peak in the $S$ phase, and declines during the $\mathrm{G} 2 \backslash \mathrm{M}$ phase, and its immunomarking characteristics allow the identification of cells in the different phases of the cycle (WOOD; SHIVIJ, 1997; MARTINS et al., 2011).

A study of the endometrial cell dynamics in mares is fundamental for the knowledge of several physiological and pathological processes that may occur during anestrous or estrous cycle phases. Based on this premise, it may be useful to establish a cell proliferation pattern between the different phases of mare estrous cycle. The present work identified the PCNA expression in endometrium samples from mares in the estrus and early diestrus, using immunohistochemical analysis.

\section{Materials and methods}

\section{Samples}

Healthy mares $(n=10)$ of no specified breed, in reproductive age, and proceeding from regional stud farms were used.

Three endometrium samples were collected from each mare, according to Kenney's parameters (KENNEY, 1978). Collection days were as follows: the first sample was collected on estrus/second day, determined with help of a stallion, and was characterized primarily by the act of urinating, eversion of the vulvar lips and tail elevation, observed in the morning, at noon and the afternoon; the second sample was collected on the ovulation day, its detection made by rectal palpation and ultrasonography. The third sample was collected seven days after the ovulation day, as determined from the second sample collection day. A total of 30 endometrial samples were obtained.

Ultrasonography was used to verify the stage of the estrous cycle and evaluate the normal patterns of the reproductive tract. The endometrial biopsies were obtained using Yeoman biopsy forceps (crocodile type) either blindly by transrectal uterus palpation and under visual ultrasound examinations. An endometrial fragment $20 \times 4 \times 3$ mm was removed, placed in Bouin's fixative, maintained for $24 \mathrm{~h}$ and then transferred to alcohol solutions (98\%, 80\% and 70\%) and sent to the laboratory for tissue processing, paraffin embedding and staining with hematoxylin and eosin (KENNEY; DOIG, 1986; SILVA; BARROS; ESQUERRE, 1987).

\section{Immunohistochemistry}

Paraffin sections $(4 \mu \mathrm{m})$ were obtained from selected uterine samples, collected on histological silanized slides (Silane, Sigma-Aldrich, MO, USA), and submitted to deparaffinization in five xylol baths (10 $\mathrm{min})$ and to rehydratation in five graded alcohol baths (5 $\mathrm{min}$ ) and three distilled water baths (5 min). Next, the specimens were treated in $30 \mathrm{~V}$ hydrogen peroxide solution diluted in 30\% methanol (Vetec, RJ, Brazil) for $30 \mathrm{~min}$ for blocking endogenous peroxidase activity. The slides were then carefully dried with paper towel, tissue sections encircled with Dako pen ${ }^{\circledR}$ (Dako, Carpinteria, CA, USA), and the specimens incubated for $1 \mathrm{~h}$ with a solution for blocking non-specific binding [Trisma- $\mathrm{NaCl}$ (Vetec, RJ, Brazil) with $1 \%$ bovine fatty-acid-free serum albumin (BSA - Sigma-Aldrich, St. Louis, MO, USA)] and $1 \%$ dried skimmed milk (Molico ${ }^{\mathrm{TM}}$ - Nestlé, SP, Brazil). After discharge of the blocking solution, tissue sections were incubated with monoclonal anti-PCNA antibody (Dako, Dinamarca, clone PC10) diluted 1:500 in ultra-pure water and incubated for $60 \mathrm{~min}$ at room temperature. Next, the slides were washed in Trizma saline solution with Tween20 TBS (Vetec, RJ, Brazil) for $5 \mathrm{~min}$ and incubated with biotinylated secondary antibody (Dako, Dinamarca, anti-mouse) 
diluted 1:200 for $40 \mathrm{~min}$. Subsequently, the tissue sections were washed with TBS and incubated with the ABC Kit (Dako, CA, USA) for $40 \mathrm{~min}$, then washed for 5 min with TBS and developed with DAB chromogen Kit (Dako, CA, USA); counterstained with Harris hematoxylin, dehydrated and mounted on slides with Permount ${ }^{\circledR}$ (Sigma-Aldrich, St. Louis, MO, USA). As a positive control, histological sections of human tongue were used and, as a negative control, endometrial sections from the mares were incubated with non-immune mouse serum.

\section{Data analyses}

The immunostaining intensity levels were assessed in a white-light optical microscope (Olympus BX41, MI, USA) focused on luminal and glandular epithelium, and using a semi-quantitative scale of 0-4 (Goodger; Rogers, 1994, adapted), and adding one degree of cell proliferation to scale (grade 5).

The percentage of immunoreactivity, subjectively estimated in each nucleus cell slot, in luminal and glandular epithelium, corresponded to degrees within the following scale. Score $\mathbf{0}$ - corresponded immunostaining absent (0\%); score 1 - one cell immunostained in each 250 counted cells (1\%); score 2 - one cell immunostained in each 50 counted cells (2\%); score 3 - one cell immunostained in each 10 counted cells (10\%); score 4 - one cell immunostained in each four counted cells (25\%); score 5 - more than two cell immunostained in each four counted cells (> 25\%). Proliferation cell counts were expressed as a percentage of the total number of 250 cells counted in four selected microscopic fields.

The average intensity for each structure was analyzed by using Kruskall Wallis and Wilcoxon test $(\alpha=5 \%)$. The results were analyzed by program system - SAEG 9.0.

\section{Results}

\section{Anti-PCNA immunoreactivity pattern}

PCNA immunohistochemical assay in endometrial sections of mares showed immunostaining in the nucleus of epithelial cells (Figures 1A and 1B), epithelium glandular (Figure 1C), stromal cells (Figures 1D and 1E) and endothelial cells (Figure 1F).

\section{Distribution of anti-PCNA immunohistochemical on the different days of endometrial collection}

For endometrium samples collected on the estrus, second day and on the ovulation day, the degree of immunostaining in luminal epithelium showed 1-5 variation, while in glandular epithelium variation was $0-1$.

For endometrium sections collected on the $7^{\text {th }}$ day after ovulation, the immunostaining results were inverse: luminal epithelium showed a degree of immunostaining varying from absent to 1 cell in 250, while glandular epithelium showed immunostaining, varying 1-3.

For samples collected on the estrus, second day, and on the ovulation day, averaged PCNA immunostaining was higher in luminal epithelium than in glandular epithelium ( $p<0.05$ ). Inversely, for endometrium sections collected on the seventh postovulation day, the averaged PCNA immunostaining was higher in glandular epithelium ( $\mathrm{p}>0.05)$.

When performing a comparison of the amount of cells stained for PCNA in the endometrium for both luminal and glandular epithelium, according to each experimental day, no difference $(p>0.05)$ was found between the estrus, second day, and the ovulation day.

Table 1 - Distribution of subjective degree of immunostaining for PCNA-antigen, on endometrial tissue sections from mares during specific days of estrous cycle - Niterói - 2010

\begin{tabular}{lcc}
\hline \multirow{2}{*}{ Day of collection } & \multicolumn{2}{c}{ Immunostaining variation } \\
\cline { 2 - 3 } & Luminal epithelium & Glandular epithelium \\
\hline estrus second day & $1-5$ & $0-1$ \\
ovulation day & $1-5$ & $0-1$ \\
$7^{\text {th }}$ postovulation day & $0-1^{\star}$ & $1-3^{\star}$
\end{tabular}

Subjective degrees of immunostaining according to Goodger and Rogers, 1994. Score: 0 - absent ( $0 \%) ; 1 \leq 1 \backslash 250$ cells ( $<2 \%) ; 2 \leq 1 \backslash 50$ cells ( $2 \%) ; 3$ $\leq 1 \backslash 10$ cells $(10 \%) ; 4 \leq 1 \backslash 4$ cells $(25 \%)$ and $5>1 \backslash 4$ cells $(>25 \%)$

${ }^{*} \mathrm{p}<0.05$ by Kruskall-Wallis test 


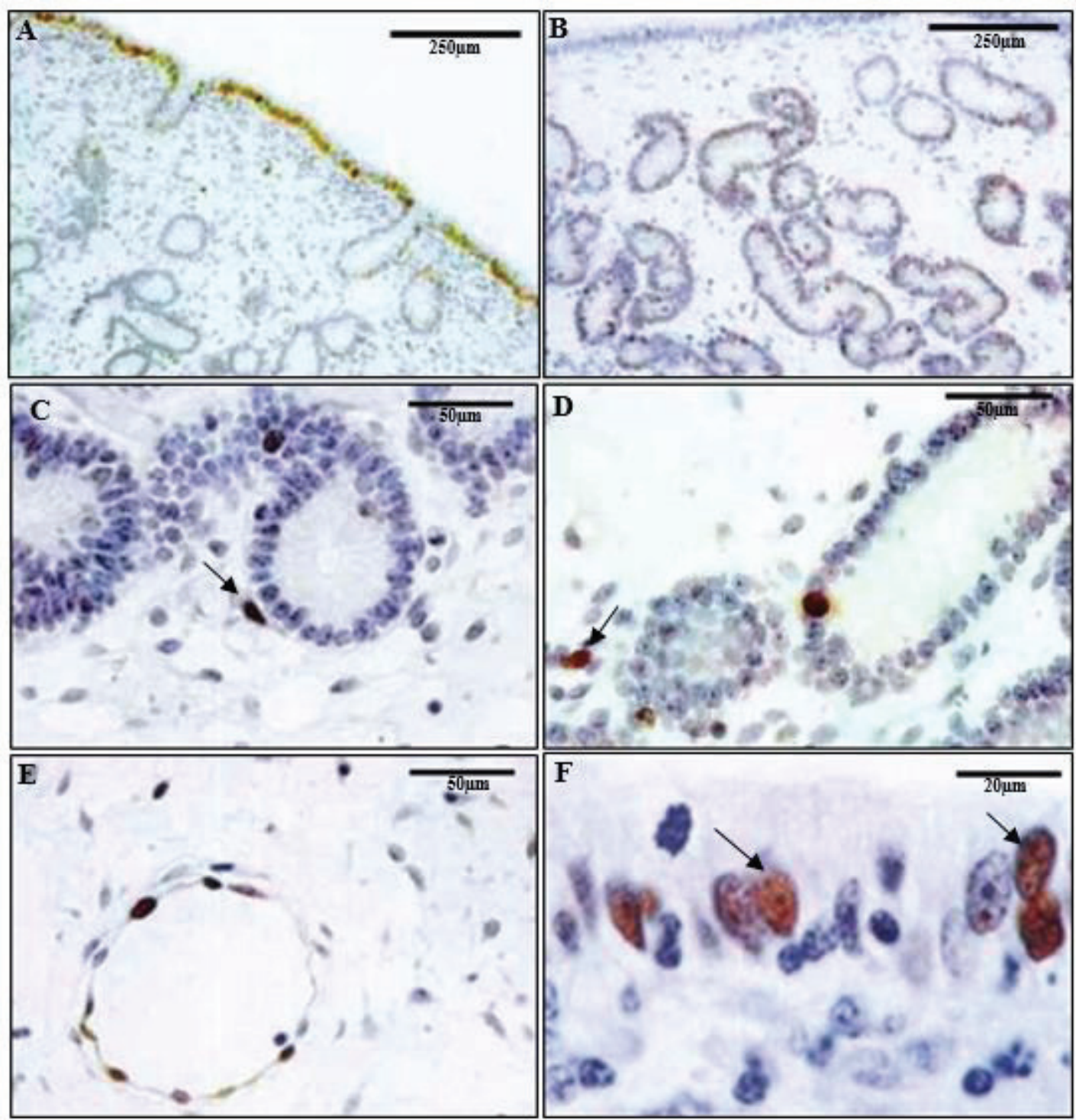

Figure 1 - Immunohistochemical for PCNA-DAB/counterstaining-hematoxylin in endometrial biopsies collected in mares. A-Immunostaining in luminal epithelium, in score five and absent in glandular epithelium, tissue section on the estrus $2^{\text {nd }}$ day, 100x magnification; B- Immunostaining in luminal epithelium, score one, and immunostaining score five in glandular epithelium, samples collected on the $7^{\text {th }}$ post-ovulation day, 100x magnification; $\mathrm{C} \backslash \mathrm{D}$ - Punctual immunostaining in stromal cells $(\rightarrow)$, sections on the estrus $2^{\text {nd }}$ day and on the ovulation day, respectively, 400x magnification; E- Endothelial cells immunostaining, $7^{\text {th }}$ post-ovulation day, 400x magnification. F- Luminal epithelium exhibiting nuclear immunostaining $(\rightarrow)$, sample collected on the ovulation day, score four, 1000x magnification Source: (MANSOUR et al., 2015) 
However, a greater $(\mathrm{p}<0.05)$ number of cells stained for PCNA was detected in the luminal epithelium on the estrus, second day, and on the ovulation day than in the seventh post-ovulation day (Figure 2).

\section{Discussion}

The distribution pattern of PCNA immunoreactivity was different between luminal and glandular compartments in present study. Immunoreactivity to PCNA shown in the samples collected in the estrus, encompassing the second day of estrus and the day of ovulation, varied strikingly when compared to samples collected at early diestrus (on the seventh day after ovulation). In the estrus, second day and on the ovulation day, the cell proliferation in the luminal epithelium was higher than in the glandular epithelium. However, endometrium samples from mares in the diestrus (on the seventh post-ovulation day) showed an inverse pattern of cell proliferation. Namely, positive nuclei predominated in the glandular portions of the endometrium, but was rare in the luminal epithelium.

The cell proliferation model observed in this study was also reported by Gerstenberg, Allen and Stewart
(1999). These authors reported cell proliferation in luminal and glandular epithelium in a higher significantly rate during estrus as compared to diestrus (on the $3^{\text {rd }}$ day after ovulation). However, the authors do not specify the day of sample collection during estrus, and if all of the biopsies within this phase were collected on the same day. They also observed a decreasing cell proliferation after ovulation, and approximately in the $5^{\text {th }}$ day of diestrus, the cell proliferation was almost absent in the luminal epithelium and in the compact stratum. Only the deep glandular secretory epithelium remained mitotically active.

However, Roberto da Costa et al. (2007) reported that PCNA immunoreactivity in glandular and luminal epithelium were increased in the luteal phase (diestrus) when compared with the follicular phase (estrus). These results differed from those presenting in this report. This fact can be explained, in part, by the difference in sample collection days, which, in this study, corresponded from the end of the follicular phase to the beginning of the luteal phase.

The nuclei of epithelial, stromal, and endothelial cells that showed immunostaining were not morphologically different, in $\mathrm{HE}$, from the negative

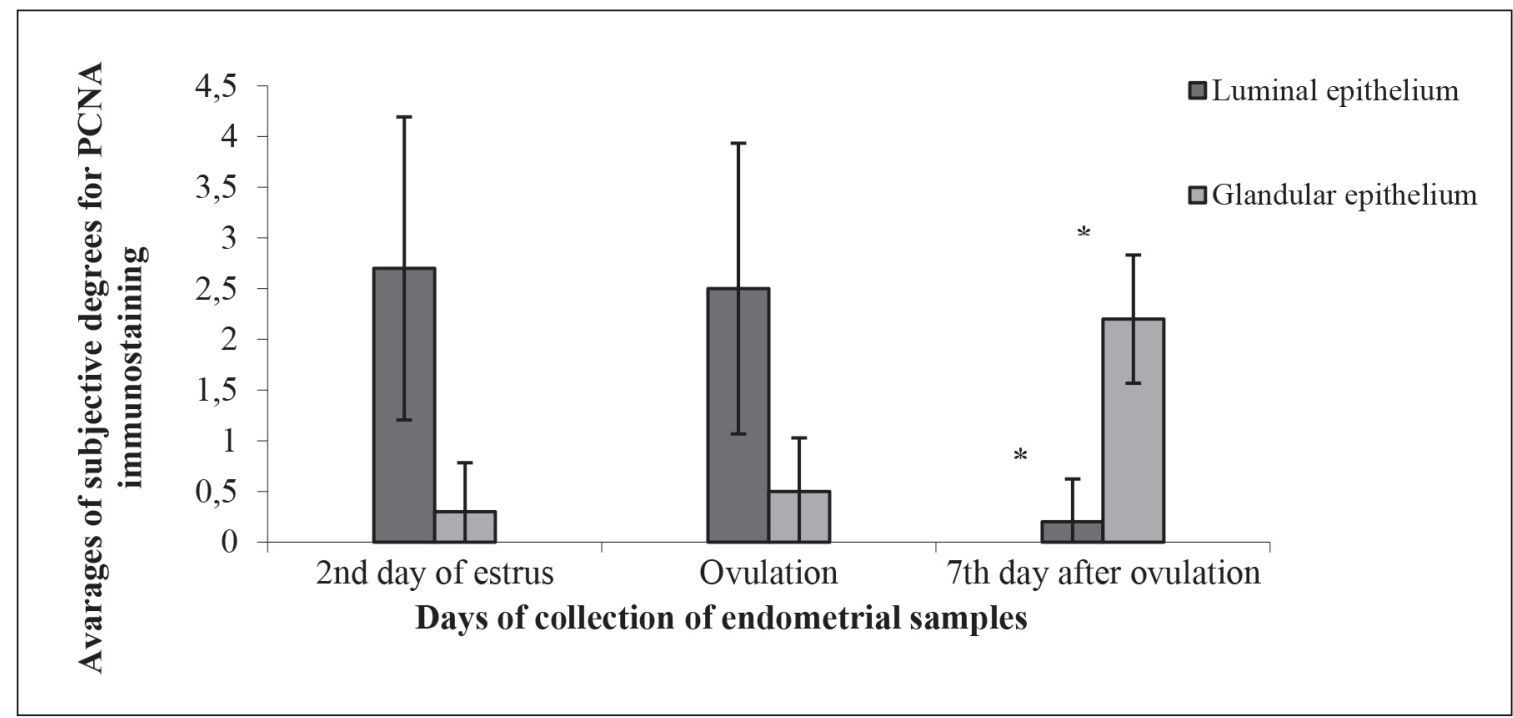

Figure 2 - Graphical representation of subjective grading for PCNA immunostaining on epithelial cells of endometrial samples collected from mares, by day collection. Bars show SEM and asterisk repre-

Source: (MANSOUR et al., 2015) sent different means among them by Wilcoxon test $(\alpha=5 \%)$ 
nuclei, except for their larger size detected in few samples. No immunostaining occurred in any of the cells presenting mitotic morphological characteristics, as those are in the $\mathrm{M}$ phase of the cell cycle, and it is compatible with previous reports (KELMAN, 1997; WOOD; SHIVIJ, 1997).

Despite the difficulty and necessary care in interpreting PCNA immunostainings (clone PC10), as described by Yu and Filipe (1993) and Martins et al. (2011), the cell proliferation distribution pattern observed in the present work was very similar to that described by Gerstenberg, Allen and Stewart (1999). However, Gerstenberg, Allen and Stewart (1999) have assessed the cell proliferation patterns in equine endometrium during the estrous and seasonal cycles, by using the Ki67 immunomarker in frozen sections.

The knowledge of cell pattern proliferation during the estrous cycle of mares is of great importance because it is necessary for the establishment of any abnormalities. Kenney and Doig (1986) and Doig and Waelchli (1993) had already signaled that the luminal and ductal epithelium (more superficial) and the deep glandular epithelium respond differently, each in its own particular way, to cyclic hormone alterations. In fact, at least in some reports, cell proliferation in endometrial epithelium of women is studied in distinct compartments, that is, luminal epithelium and glandular epithelium (GOODGER; ROGERS, 1994; WINGFIELD et al., 1995).

Thus, as suggested by Gerstenberg, Allen and Stewart (1999), the proliferation of the secretory glandular epithelium during the initial stage of diestrus in mares may be a late response to estrogen peripheral levels decreasing, rather than a direct response to increased levels of progesterone. When the corpus luteum becomes mature, the high progesterone concentration would then put an end on the glandular epithelium proliferation in the initial stage of diestrus turning it into a secretory epithelium. Lai et al. (2000) also observed a similar proliferative pattern in endometrium of rodents where high PCNA expression was present in the luminal and glandular epithelial cells when stimulated by estrogen. Stromal cells and endothelial cells of equine endometrium also presented reactivity to PCNA, although no differentiation in pattern was recognized between days of collection throughout the estrous cycle, as occurred for endometrial epithelium.

Endometrial cell proliferation may also be associated with diverse pathological conditions. In women, cell proliferation was significantly lower in cases of chronic non-specific endrometritis when compared with the proliferative endometrium group (YORUKOGLU; KUYUCUOGLU, 1998). Therefore, it would be of interest to establish the relation between the proliferative activity of equine endometrial cells and the inflammatory processes that assail them, which constitute an important cause of subfertility.

Immunohistochemical assessment of endometrium using the anti-PCNA antibody may also be complementary to fertility prognosis, with basis on two endometrial biopsy samples, obtained before and after specific uterine treatment, respectively (RICKETTS; ALONSO, 1991). Treatment with intrauterine infusion of kerosene, for example, is based on the removal of an endometrium layer to permit the growth of new functional tissue (BRACHER; NEUSCHAEFER; ALLEN, 1991).

It was concluded that luminal epithelial cell proliferation is higher during estrus and lower during early diestrus, whereas glandular epithelial cells show higher proliferation during diestrus. In addition, immunochemical reaction using the PC10 clone for detection of PCNA allowed the identification of proliferating cells in equine endometrium sections previously fixed in Bouin's fluid, and with no need for antigen recovery. Thus, investigation of cell proliferation using the immunohistochemical technique may be employed in future studies for diverse applications, e.g., inflammatory processes, particularly in mares that are prone to endometritis; fertility prognostics, through cell renewal and the association of such molecules and related alterations; and several subfertility conditions. 


\section{References}

BRACHER, V.; NEUSCHAEFER, A.; ALLEN, W. R. The effect of intra-uterine infusion of kerosene on the endometrium of mares. Journal of Reproduction and Fertility, v. 44, p. 706-707, 1991.

BROW, T. R. Steroid hormones, overview. Encyclopedia of Reproduction. $4^{\text {th }}$ ed. San Diego: Academic Press, 1999. p. 634-661.

DOIG, P. A.; WAELCHLI, R. O. Endometrial biopsy. In: McKINNON, A. O.; VOSS, J. L. Equine reproduction. Malvern: Lea \& Febiger, 1993. p. 225-233.

EIGENHEER-MOREIRA, J. F.; FERNANDES, F. T.; QUEIROZ, F. J. R.; PINHO, T. G.; FERREIRA, A. M. R. Estudo comparativo de éguas repetidoras ou não de cio através da avaliação histológica do endométrio e das concentrações plasmáticas de progesterona. Pesquisa Veterinária Brasileira, v. 27, n. 12, p. 506-512, 2007. Available from: <http://www.scielo.br/scielo.php?pid=S0100736X2007001200007\&script=sci_arttext>. Viewed: 21 Dec. 2015. doi: http://dx.doi.org/10.1590/S0100-736X2007001200007.

GERSTENBERG, C.; ALLEN, W. R.; STEWART, F. Cell proliferation patterns in the equine endometrium throughout the non-pregnant reproductive cycle. Journal of Reproduction and Fertility, v. 116, n. 1, p. 167-175, 1999. Available from: <http:// www.reproduction-online.org/content/116/1/167>. Viewed: 21 Dec. 2015. doi: http://dx.doi.org/10.1530/jrf.0.1160167.

GOODGER, A. M.; ROGERS, P. A. W. Endometrial endothelial cell proliferation during the menstrual cycle. Human Reproduction, v. 9 , n. 3, p. 399-405, 1994.

HAFEZ, E. S. E.; JAINUDEEN, M. R.; ROSNINA, Y. Hormônios, fatores de crescimento e reprodução. In: HAFEZ, E. S. E.; HAFEZ, B. Reprodução animal. 7. ed. Barueri: Manole, 2004. p. 33-53.

KELMAN, Z. PCNA: structure, functions and interactions. Oncogene, v. 14, p. 629-640, 1997.

KENNEY, R. M. Cyclic and pathologic changes of the mare endometrium as detected by biopsy, with a note on early embrionic death. Journal of the American Veterinary Medical Association, v. 172 , n. 3, p. 241-262, 1978

KENNEY, R. M.; DOIG, P. A. Equine endometrial biopsy. In: MORROW, D. A. Current terapy in theriogenology. $2^{\text {nd }}$ ed. Philadelphia: Saunders Company, 1986. p. 723-729.

LAI, M. D.; LEE, L. R.; CHENG, K. S.; WING, L. Y. Expression of proliferating cell nuclear antigen in luminal epithelium during the growth and regression of rat uterus. Journal of Endocrinology, v. 166, p. 87-93, 2000. Available from: <http://intl-joe.endocrinologyjournals.org/content/166/1/87.short>. Viewed: 21 Dec. 2015. doi: http://dx.doi.org/10.1677/joe.0.1660087.

MANSOUR, G. D.; FERREIRA, A. M. R.; FERNANDES, F. T.; HENRY, M. Histomorphometry of epithelial structures of the mare's endometrium. Revista Brasileira de Ciência Veterinária, v. 11, n. 1-2, p. 42-46, 2004.

MANSOUR, G. D.; HENRY, M.; FERREIRA, A. M. R. Immunohistochemical study of equine endometrial extracellular matrix during estrous cycle. Journal of Comparative Pathology, v. 129, n. 4 , p. $316-319,2003$. Available from: <http://www. sciencedirect.com/science/article/pii/S0021997503000483>.
Viewed: 21 Dec. 2015. doi: http://dx.doi.org/10.1016/S00219975(03)00048-3.

MARTINS, D. C.; EIGENHEER-MOREIRA, J. F.; LEITE, J. D. A.; FERREIRA, A. M. R. Biópsias endometriais de éguas: avaliação imuno-histoquímica e definição de protocolo. Revista Brasileira de Ciência Veterinária, v. 18, n. 2-3, p. 62-66, 2011.

MIYACHI, K.; FRITZLER, M. J.; TAN, E. M. Autoantibody to a nuclear antigen in proliferating cells. Journal of Immunology, v. 121, n. 6, p. 2228-2234, 1978.

MUSKHELISHVILI, L.; LATENDRESSE, J. R.; KODELL, R. L.; HENDERSON, E. B. Evaluation of cell proliferation in rat tissues with BrdU, PCNA, Ki-67 (MIB-5) immunohistochemistry and in situ hybridization for histone mRNA. Journal of Histochemistry \& Cytochemistry, v. 51, n. 12, p. 1681-1688, 2003. Available from: $<$ http://jhc.sagepub.com/content/51/12/1681>. Viewed: 21 Dec. 2015. doi: http://dx.doi.org/10.1177/002215540305101212.

PRIEDKALNS, J. Female reproductive system. In: DELLMANN, $H$. D. Textbook of veterinary histology. $4^{\text {th }}$ ed. Philadelphia: Lea \& Febiger, 1993.p. 233-242.

RICKETTS, S. W.; ALONSO, S. Assessment of the breeding prognoses of mares using paired endometrial biopsy techniques. Equine Veterinary Journal, v. 23, n. 3, p. 185188, 1991. Available from: <http://onlinelibrary.wiley.com/ doi/10.1111/j.2042-3306.1991.tb02751.x/abstract>. Viewed: 21 Dec. 2015. doi: http://dx.doi.org/10.1111/j.2042-3306.1991. tb02751.x.

ROBERTO DA COSTA, R. P.; SERRÃO, P. M.; MONTEIRO, S.; PESSA, P.; ROBALO SILVA, J.; FERREIRA-DIAS, G. Caspase3 -mediated apoptosis and cell proliferation in the equine endometrium during the oestrous cycle. Reproduction, Fertility and Development, v. 19, n. 8, p. 925-932, 2007. Available from: $<$ http://www.publish.csiro.au/?paper=RD06159>. Viewed: 21 Dec. 2015. doi: http://dx.doi.org/10.1071/RD06159.

SILVA, C. A. M.; BARROS, S. S.; ESQUERRE, R. A. A biópsia endometrial na avaliação da fertilidade na égua. Pesquisa Veterinária Brasileira, v. 7, p. 131-133, 1987.

WINGFIELD, M.; MACPHERSON, A.; HEALY, D. L.; ROGERS, P. A. Cell proliferation is increased in the endometrium of women with endometriosis. Fertility and Sterility, v. 64, n. 2, p. 340-346, 1995.

WOOD, R. D.; SHIVJI, M. K. K. Which DNA polymerases are used for DNA-repair in eukaryotes? Carcinogenesis, v. 18, n. 4 , p. 605-610, 1997.

YORUKOGLU, K.; KUYUCUOGLU, F. Chronic nonspecific endometritis. General \& Diagnostic Pathology, v. 143, n. 5-6, p. 287-290, 1998

YU, C. C. W.; FILIPE, M. I. Update on proliferation-associated antibodies applicable to formalin-fixed paraffin-embedded tissue and their clinical applications. Histochemical Journal, v. 25, n. 12, p. 843-853, 1993. Available from: <http://link.springer.com/ article/10.1007\%2FBF02388205>. Viewed: 21 Dec. 2015. doi: http://dx.doi.org/10.1007/BF02388205. 